\title{
Trekking Tourism in Spain: Analysis of the Sociodemographic Profile of Trekking Tourists for the Design of Sustainable Tourism Services
}

\author{
Jorge Rojo-Ramos ${ }^{1}{ }^{\mathbb{D}}$, Rubén Martín-Carmona ${ }^{1}$, Carmen Galán-Arroyo ${ }^{1}$, \\ Fernando Manzano-Redondo 1,*(D), Miguel Ángel García-Gordillo ${ }^{2}$ (D) and \\ José Carmelo Adsuar ${ }^{1}$ (D) \\ 1 Department of Health, Economy, Motricity and Education (HEME) Research Group, University of \\ Extremadura, Avda. de la Universidad s/n, 10003 Cáceres, Spain; jorgerr@unex.es (J.R.-R.); \\ mcruben@hotmail.com (R.M.-C.); mamengalan.tq@gmail.com (C.G.-A.); jadssal@unex.es (J.C.A.) \\ 2 Faculty of Administration and Business, Universidad Autónoma de Chile, Sede Talca 3467987, Chile; \\ miguelgarciagordillo@gmail.com \\ * Correspondence: fmanzanoa@alumnos.unex.es
}

Received: 18 September 2020; Accepted: 12 October 2020; Published: 2 November 2020

\begin{abstract}
The practice of sports activities related to nature and the environment is a social and tourist phenomenon that is increasingly popular. In this paper, we aim to find and analyze the sociodemographic characteristics of tourists who take trips in order to find and enjoy trekking opportunities. Thus, it seeks to facilitate the design of offers of more sustainable activities aimed at this public which contribute to the development of an efficient tourism model to preserve the environment. The research has been carried out by analyzing the data obtained from the travel file of the Resident Tourism Survey of the National Statistical Institute for 2019. The profile of the trekking tourist in Spain is Spanish, married, lives as a couple, and very well educated. Participants are usually busy and use their car, other private vehicles, or destination-provided transportation. They tend to stay in the homes of family, friends, or their employer on their trips. This information is relevant for the design of sustainable tourism products since by knowing the priorities of this profile of tourists, more sustainable activities can be elaborated and better development and protection of the environment can be achieved.
\end{abstract}

Keywords: trekking; sustainable tourism; tourist profile; sports tourism

\section{Introduction}

Active tourism (AT) or adventure tourism is one of the fastest growing sectors of tourism in the world [1]. It is booming, with beach tourism or organized trips becoming increasingly less important, since AT accounts for $2 \%$ of world tourism due to the growing need to escape from urban environments, break with everyday life, and experience risk and adrenaline in nature without the need for previous experience. Tourists want to enjoy the emotional impact that these practices bring and the pleasure of transmitting the experience to family and friends [2].

The World Tourism Organization identified a favorable relationship between AT and nature at an international level, in line with what was exposed by Molina Navarro et al. [3] who affirm that these practices have gone from being mere leisure activities to providing important value in the areas of the economy, tourism, the environment, and politics.

There are numerous definitions of AT or adventure tourism [4-6], such as sports tourism, physical sports activities in the natural environment, and leisure and adventure tourism, provided by different authors, decrees, or bodies. However, to unify criteria and understand the terminological 
concept of AT adopted for this research, we will use the one provided by Mediavilla Saldaña [7] which defines as AT as

... the tourist service, which seeks to satisfy the personal needs of physical activity, recreation and leisure, in a specific time and a specific environment, in which it is necessary the integral participation of the subjects through the acquisition of previous knowledge and the commitment of the implication that the own physical and mental activity demands.

-Mediavilla Saldaña [7] (p. 69)

In recent decades, it has been possible to highlight the growing influence that the ecological paradigm has generated in different social activities, highlighting physical activities in the natural environment as some of the most appreciated and valued by society [8]. Changes are being observed in people's lifestyles in search of healthier practices that integrate physical exercise and contact with nature. For this reason, there is an increasing demand for experience-based tourism, which increases the types of tourism in nature at the same time [9].

To achieve a global definition of trekking, reference must be made to an AT sports activity, which may be assigned specific equipment or materials, in different terrains and climates, being in contact with nature and with a certain component of jeopardy and risk $[10,11]$. To be more specific, the most common or classic form of trekking is mountain trekking. However, there are other types such as desert, tropical, glacial, polar, river, swamp, and volcanic trekking [11]. In addition, trekking is a physical sports activity that is deeply rooted in these trends of healthy living [12] and also has a tourist component, so it can be conceived as a product within a destination. Spain has an important network of ancient trails, many of which are signposted, making them a recreational tourist attraction [13].

According to Tojo and García [14], nature tourism and ecodevelopment should sail in the same direction, since they complement each other perfectly. However, some aspects must be taken into account when it comes to making a territory more dynamic for sustainability: creating a ceiling on the number of visitors, controlling the resource use of the local attractions, and avoiding the seasonality of supply. In this way, it would be possible to divide the influx of tourists and not overwhelm the environment at certain times, and have good plans for the maintenance and preservation of the natural environment.

Sustainability is understood as a complex and integral concept that brings together diverse claims and approaches. The environmental, economic, and socio-cultural aspects of tourism development constitute the principles of sustainability. It is vitally important to establish an appropriate balance between these three dimensions to ensure long-term sustainability [15]. For an activity such as trekking to be considered a sustainable tourism product, it must respect the natural resources of the environment, not contaminate and not generate social tensions or loss of cultural identity [15].

One of the aims of trekking for sustainability is to define viable projects and reconcile the economic, social, and environmental aspects of human activities. Therefore, it tries to continue progressing in these areas without having to destroy the environment. It contributes to trying to achieve the different sustainable development goals set by the UN [16].

Nature-based tourism, such as trekking, is one of the few economic uses of some areas, parks, or nature trails that is compatible with the protection of the environment and its wildlife [17].

Such treks and tours are quite safe as long as they are well directed and planned, the trekking route is well known, and the organizers are knowledgeable about the environment and wildlife [17].

In some places, trekking has brought employment and income opportunities to communities along the major trekking routes, along with modern values, lifestyles, and technologies. Nyaupane et al. [18] claim those perceptions of residents varied, because economic growth and improved social services were favored, but residents were concerned about changes in the culture and the climate.

In the search for this sustainable tourism, we must generate a model for economic development that allows us to improve people's life quality. This will ensure that the tourists or visitors have a good quality experience while also ensuring the product is compatible with the existing natural resources. 
This will make it possible to maintain environmental quality, without endangering the deterioration or depletion of the resources and assuring its permanence in the long term $[16,19,20]$.

Even though several types of research [1,3,9] try to discover the motivations and offers of tourism, nature, and trekking, for the time being, the majority profile of people who carry out this type of tourism, as well as their previous planning and organization [11], is not known.

This study joins other previous studies such as Różycki and Dryglas [11], following the literature streams of knowing the type or profile of the person who makes this type of tourism, the personal situation, means of transport used and even relationships which establish among tourists who share the passion of trekking. For all these reasons, it is said that trekking is a phenomenon of the turn of the XX and XXI century, through which they seek contact with nature and at the same time it allows checking themselves [11]. Therefore, this study aims to know the socio-demographic background of national trekking tourists, thus facilitating the work of designing more sustainable and environmentally friendly activities and increasing knowledge about all aspects that this type of tourism can cover. It focuses on the profile of tourists who seek trekking among their reasons for traveling, trying to achieve full tourist satisfaction, reducing the impact on the environment, and contributing to the maintenance of the diversity of natural resources and the maximum profitability of the tourist destination.

\section{Materials and Methods}

\subsection{Participants}

The sample was comprised of 64,221 persons who participated in the National Statistics Institute's (NSI) tourism survey of residents in the year 2019, from which a total of 12,072 participants were selected who indicated trekking as an activity carried out on their trip in question 39 of the questionnaire. Of the total sample, $49.2 \%(n=5941)$ were men with a mean age of 50.52 years and $50.8 \%(n=6131)$ were women with a mean age of 50.02 years. The type of sampling used for the selection of the sample was a stratified two-stage random sampling, using the collaborating dwellings in the Continuous Household Survey (CHS). Therefore, the actual sample used for this study may be considered a subsample of the 58,000 households in the CHS.

Mentioning the processing of data, the NSI carries out the appropriate measures to preserve the confidentiality of the same from the time the data is collected until its subsequent publication. Besides, the questionnaire itself includes a clause informing about the protection of the data collected.

The NSI takes the necessary logical, physical, and administrative measures to ensure that the protection of confidential data is effective, from data collection to publication.

A legal clause is included in the survey questionnaires informing about the protection of the data collected, keeping those that allow direct identification exclusively during the information processing phase. Once the results tables were published, the information was analyzed in detail to prevent any confidential data from being deduced. Finally, in the microdata files, categories of the variables have been included so that the informants could not be identified.

\subsection{Methods}

The data collection was obtained from the questionnaire of the Tourism Survey of Residents (RTS/FAMILITUR) of the National Institute of Statistics, composed of 51 items, grouped in three areas (sociodemographic area, travel area, and excursions area), two modules (annual participation module and module $\mathrm{Q}$ ) and an annex (annex: a previous version of the excursions area).

The main variable of the study is trekking as an activity practiced during the trips made by our sample. Within the survey, the following secondary variables belonging to the socio-demographic profile were selected for study: gender, age, home country, nationality, marital status, cohabitation with a partner, level of studies, economic activity, the professional status in the job performed, type of household, secondary housing availability, present in the sociodemographic area of the questionnaire and type of accommodation and main means of transport, corresponding to the area of travel. 
To access the data obtained in the survey, we used the microdata files from the 2019 database available on the INE website (https://www.ine.es/dyngs/INEbase/es/operacion.htm?c= Estadistica_Cycid $=1254736176990 \mathrm{ymenu}=$ resultadosysecc $=1254736195369 \mathrm{yid}=1254735576863 \#$ !tabs-1254736195369). Once all the files were obtained, our action was based on compiling the data obtained in the same Excel database to facilitate their processing in the statistical program used for their further analysis.

\subsection{Statistics}

The analysis of the collected data was performed with the Statistical Package for Social Sciences (SPSS) version 23.0 for MAC. The values for each of the variables studied were obtained from the percentage that makes up each of the items. The age related data are presented as mean and standard deviation and as median and interquartile range. To analyze whether the variables met the assumption of normality, Kolmogorov Smirnov's test was used, which indicated that the assumption was not met, so it was decided to use non-parametric tests. Pearson's Chi-square test was used to analyze the differences between each of the items studied and the gender variable. Mann Whitney's U-test was used to analyze the statistically significant differences by gender for the age variable.

For all statistical tests, the significance was established in ${ }^{*} p<0.05$.

\section{Results}

Table 1 shows the distribution of participants by gender, age, and home country.

Table 1. Frequency distribution of home country and age of the sample $(\mathrm{N}=64,221)$.

\begin{tabular}{ccccc}
\hline Variable & \multicolumn{5}{c}{ Categories } \\
\hline & Total & Man & Woman & $p$ \\
\cline { 2 - 5 } & $\mathbf{N ~ ( \% )}$ & $\mathbf{N ~ ( \% )}$ & $\mathbf{N ~ ( \% )}$ & \\
\hline Participants & $12,072(50.8)$ & $5941(49.2)$ & $6131(50.8)$ & \\
\hline Age (years) & & & & 0.16 \\
Median (IQR) & $51(19)$ & $51(18)$ & $50(18)$ & \\
Mean (SD) & $50.02(13.72)$ & $50.52(13.93)$ & $49.53(13.0)$ & \\
\hline Home country & $\mathbf{N ~ ( \% )}$ & $\mathbf{N ~ ( \% )}$ & $\mathbf{N ~ ( \% )}$ & \\
Spain & $11,657(96.6)$ & $5777(97.2)$ & $5880(95.9)$ & 0.14 \\
Foreign & $415(3.4)$ & $164(2.8)$ & $251(4.1)$ & \\
\hline
\end{tabular}

Table 2 shows the frequency distribution of the nominal variables (nationality, marital status, couple cohabitation, and type of household) and the ordinal variable (level of studies) studied. All of them are distributed by gender, also analyzing the existence or not of statistically significant differences from Pearson's Chi-Square test. 
Table 2. Distribution of frequencies of the variables nationality, marital status, cohabitation with a partner, level of studies and type of household.

\begin{tabular}{|c|c|c|c|c|}
\hline \multirow[t]{2}{*}{ Variable } & \multicolumn{3}{|c|}{ Frequencies } & \multirow[b]{2}{*}{$p^{*}$} \\
\hline & Total & Man & Woman & \\
\hline Nationality & N (\%) & N (\%) & N (\%) & \multirow{4}{*}{0.02} \\
\hline Only Spanish & $11,817(97.9)$ & $5831(98.1)$ & $5986(97.6)$ & \\
\hline Only Foreign & $151(1.3)$ & $64(1.1)$ & $87(1.4)$ & \\
\hline Spanish and Foreign & $104(0.9)$ & $46(0.8)$ & $58(0.9)$ & \\
\hline Marital status & N (\%) & N (\%) & N (\%) & \multirow{6}{*}{$<0.01$} \\
\hline Single & $3558(29.5)$ & $1785(30)$ & $1773(28.9)$ & \\
\hline Married & $6958(57.6)$ & $3499(58.9)$ & $3459(56.4)$ & \\
\hline Widowed & $373(3.1)$ & $105(1.8)$ & $268(4.4)$ & \\
\hline Separate & $185(1.5)$ & $103(1.7)$ & $82(1.3)$ & \\
\hline Divorced & $998(8.3)$ & 449 (7.6) & $549(9)$ & \\
\hline $\begin{array}{c}\text { Cohabitation with a } \\
\text { Partner }\end{array}$ & $\mathbf{N}(\%)$ & $\mathbf{N}(\%)$ & $\mathbf{N}(\%)$ & \multirow{4}{*}{0.03} \\
\hline $\begin{array}{c}\text { Cohabitation with their } \\
\text { spouse }\end{array}$ & $6706(55.6)$ & $3367(56.7)$ & $3339(54.5)$ & \\
\hline $\begin{array}{l}\text { Cohabitation with a } \\
\text { common-law partner }\end{array}$ & 944 (7.8) & 465 (7.8) & 479 (7.8) & \\
\hline $\begin{array}{c}\text { Not cohabitation together as } \\
\text { a couple }\end{array}$ & $4422(36.6)$ & 2109 (35.5) & $2313(37.7)$ & \\
\hline Level of studies & N (\%) & $\mathbf{N}(\%)$ & $\mathbf{N}(\%)$ & \multirow{5}{*}{$<0.01$} \\
\hline Primary education or less & $363(3)$ & 199 (3.3) & $164(2.7)$ & \\
\hline $\begin{array}{l}\text { Secondary education, first } \\
\text { stage }\end{array}$ & 1828 (15.1) & 987 (16.6) & 841 (13.7) & \\
\hline $\begin{array}{l}\text { Secondary education, } \\
\text { second stage }\end{array}$ & $2616(21.7)$ & $1319(22.2)$ & $1297(21.2)$ & \\
\hline Post-secondary education & $7214(59.8)$ & 3405 (57.3) & 3809 (62.1) & \\
\hline Type of household & N (\%) & N (\%) & $\mathbf{N}(\%)$ & \multirow{7}{*}{$<0.01$} \\
\hline Single household & $2347(19.4)$ & $1195(20.1)$ & $1152(18.8)$ & \\
\hline $\begin{array}{l}\text { Single parent cohabitation } \\
\text { with a child }\end{array}$ & $978(8.1)$ & $384(6.5)$ & $594(9.7)$ & \\
\hline $\begin{array}{l}\text { Couple without children } \\
\text { cohabitation at home }\end{array}$ & $3179(26.3)$ & $1574(26.5)$ & $1605(26.2)$ & \\
\hline $\begin{array}{l}\text { Couple with children } \\
\text { cohabitation at home }\end{array}$ & $4971(41.2)$ & $2564(43.2)$ & 2407 (39.3) & \\
\hline Other household & $597(4.9)$ & $224(3.8)$ & $373(6.1)$ & \\
\hline $\begin{array}{c}\text { Secondary housing } \\
\text { availability }\end{array}$ & $\mathbf{N}(\%)$ & $\mathbf{N}(\%)$ & $\mathbf{N}(\%)$ & \\
\hline Yes & $5140(42.6)$ & $2565(43.2)$ & $2575(42)$ & \multirow{2}{*}{0.19} \\
\hline No & $6932(57.4)$ & $3376(56.8)$ & $3556(58)$ & \\
\hline
\end{tabular}

Note: Analysis of statistically significant differences with respect to the Pearson Chi-square test $p^{*}$.

Table 3 refers to the professional profile of our sample and presents the distribution of frequencies of the variables relating to economic activity and the professional status in the job performed. Higher rates are obtained in the categories of employed persons with a permanent contract. 
Table 3. Frequency distribution of the variables under study.

\begin{tabular}{|c|c|c|c|c|}
\hline \multirow[t]{2}{*}{ Variable } & \multicolumn{3}{|c|}{ Frequencies } & \multirow[b]{2}{*}{$p^{*}$} \\
\hline & Total & Man & Woman & \\
\hline Relationship between economic activity & N (\%) & $\mathbf{N}(\%)$ & N (\%) & \multirow{5}{*}{$<0.01$} \\
\hline Busy & $\begin{array}{l}8135 \\
(67.4)\end{array}$ & $\begin{array}{c}4131 \\
(69.5)\end{array}$ & $\begin{array}{c}4004 \\
(65.3)\end{array}$ & \\
\hline Unemployed & $758(6.3)$ & $243(4.1)$ & $515(8.4)$ & \\
\hline Retired & $\begin{array}{c}1989 \\
(16.5)\end{array}$ & $\begin{array}{l}1218 \\
(20.5)\end{array}$ & $771(12.6)$ & \\
\hline Other inactive & $1139(9.4)$ & $318(5.4)$ & $821(13.4)$ & \\
\hline Professional status in the job performed & $\mathbf{N}(\%)$ & $\mathbf{N}(\%)$ & $\mathbf{N}(\%)$ & \multirow{5}{*}{$<0.01$} \\
\hline $\begin{array}{c}\text { Employer, professional or self-employed person who } \\
\text { employs others }\end{array}$ & $471(3.9)$ & $302(5.1)$ & $169(2.8)$ & \\
\hline $\begin{array}{l}\text { Employer, professional or self-employed person who } \\
\text { does not employ others }\end{array}$ & $669(5.5)$ & $391(6.6)$ & $278(4.5)$ & \\
\hline Employee or employee with a permanent contract & $\begin{array}{l}5989 \\
(49.6)\end{array}$ & $\begin{array}{c}3039 \\
(51.2)\end{array}$ & $\begin{array}{l}2950 \\
(48.1)\end{array}$ & \\
\hline Employee or employee with a temporary contract & $1006(8.3)$ & $399(6.7)$ & $607(9.9)$ & \\
\hline
\end{tabular}

Note: Analysis of statistically significant differences regarding the Pearson Chi-square test $p^{*}$.

Table 4 shows the distribution of frequencies according to the gender of the variables Type of Accommodation and Main Means of Transport. With regard to the type of accommodation, it is observed that most tourists choose to stay in the homes of relatives, friends, or companies. It should be noted that the most used means of transport by our sample are the own vehicle and the airplane, being these ones the most polluting and producing a higher carbon footprint. If it seems that it is the woman who makes the greater use of public transport such as the bus.

Table 4. Distribution of frequencies according to the gender of the variables Type of Accommodation and Main Means of Transport.

\begin{tabular}{cccc}
\hline Variable & \multicolumn{3}{c}{ Frequencies } \\
\hline Total & Man & Woman & $p^{*}$ \\
\hline Type of Accommodation & $\mathbf{N ~ ( \% )}$ & $\mathbf{N ~ ( \% )}$ & $\mathbf{N ~ ( \% )}$ \\
\hline Hotel or apartment hotel & $1473(12.2)$ & $751(12.6)$ & $722(11.8)$ \\
Hostel & $250(2.1)$ & $115(1.9)$ & $135(2.2)$ \\
Complete housing for rent & $784(6.5)$ & $383(6.4)$ & $401(6.5)$ \\
Room for rent in a private & $21(0.2)$ & $11(0.2)$ & $10(0.2)$ \\
home & $696(5.8)$ & $338(5.7)$ & $358(5.8)$ \\
Rural tourism accommodation & $149(1.2)$ & $83(1.4)$ & $66(1.1)$ \\
Shelter & $403(3.3)$ & $194(3.3)$ & $209(3.4)$ \\
Camps & $15(0.1)$ & $10(0.2)$ & $5(0.1)$ \\
Cruise & $48(0.4)$ & $23(0.4)$ & $25(0.4)$ \\
Other market & $3784(31.1)$ & $1870(31.5)$ & $1914(31.2)$ \\
accommodations & $4161(34.5)$ & $1993(33.5)$ & $2168(35.4)$ \\
Home ownership & $7(0.1)$ & $0(0)$ & $7(0.1)$ \\
Family, friend or company & $12(0.1)$ & $8(0.1)$ & $4(0.1)$ \\
housing & $269(2.2)$ & $162(2.7)$ & $107(1.7)$ \\
Shared use housing & & & \\
Swapped homes & & &
\end{tabular}


Table 4. Cont.

\begin{tabular}{|c|c|c|c|c|}
\hline \multirow[t]{2}{*}{ Variable } & \multicolumn{4}{|c|}{ Frequencies } \\
\hline & Total & Man & Woman & $p^{*}$ \\
\hline Main means of transport & $\mathbf{N}(\%)$ & $\mathbf{N}(\%)$ & N (\%) & \\
\hline Air transport & $861(7.1)$ & 407 (6.9) & $454(7.4)$ & \\
\hline Cruise & $11(0.1)$ & $7(0.1)$ & $4(0.1)$ & \\
\hline Ferry & $102(0.8)$ & $54(0.9)$ & $48(0.8)$ & \\
\hline Own, leased or rented boat & $1(0.0)$ & $0(0)$ & $1(0.0)$ & \\
\hline $\begin{array}{c}\text { Car or other private cars } \\
\text { owned or leased }\end{array}$ & $10,252(84.9)$ & $5146(86.6)$ & $5106(83.3)$ & \\
\hline Car or other private cars & & & & $<0.01$ \\
\hline $\begin{array}{l}\text { rented without a driver from } \\
\text { rental companies }\end{array}$ & $79(0.7)$ & $33(0.6)$ & $46(0.8)$ & \\
\hline $\begin{array}{l}\text { Taxis or carpooling with } \\
\text { payment to the driver }\end{array}$ & $14(0.1)$ & $9(0.2)$ & $5(0.1)$ & \\
\hline $\begin{array}{l}\text { Car or carpooling with } \\
\text { payment to the driver }\end{array}$ & $21(0.2)$ & $8(0.1)$ & $13(0.2)$ & \\
\hline Bus & $444(3.7)$ & $148(2.5)$ & $296(4.8)$ & \\
\hline Train & $256(2.1)$ & $108(1.8)$ & $148(2.4)$ & \\
\hline Non-motorized land transport & $10(0.1)$ & $8(0.1)$ & $2(0.1)$ & \\
\hline Other means of transport & $21(0.2)$ & $13(0.2)$ & $8(0.1)$ & \\
\hline
\end{tabular}

Note: Analysis of statistically significant differences regarding the Pearson Chi-square test $p^{*}$.

\section{Discussion}

Depending on the results obtained, the purpose of profile evaluation is to facilitate the work of designing more sustainable and environmentally friendly activities, by sustainable development goals and in favourable conditions for tourists, thus, achieving the satisfaction of all structures.

The main finding of the study has been the description of the profile of the trail tourist according to gender. It is noteworthy that statistically significant differences were obtained in all the variables studied according to gender except in the "secondary dwelling" variable.

The first variable studied was the average age of our sample at 50.02 years, in line with Beedie and Hudson [21] who state that more than $77 \%$ of this type of tourist is over 30 years old. Specifically, tourists between $41-55$ years of age tend to choose trekking as an adventure tourism activity, increasing in percentage with age [22].

Regarding the nationality of the sample participants, we highlight that $97.7 \%$ had exclusively Spanish nationality, with a significant difference in nationality by gender $(p=0.02)$, specifically in foreign nationality, since 64 men had exclusively foreign nationality as opposed to 87 women who had only foreign nationality.

Concerning the marital status of the sample, we highlight that $57.6 \%$ were married. A significant difference was also obtained according to gender $(p<0.01)$, specifically observing that 268 women were widows, and only 105 were men.

Regarding cohabitation, most of the participants lived with their spouse (55.6\%), also obtaining a significant difference, but not as high as in the previous variables according to gender $(p=0.03)$.

The predominant level of education is Post-Secondary Education (59.8\%), with a very significant difference according to gender, especially in this category $(p<0.01)$, in line with Balderas Elorza [23]. Also, Mill [24] points out that an element that encourages tourism and sport is the increase of the educational level.

Most of the sample are employed people (67.4\%) followed by retirees (16.5\%). Again, significant differences were obtained according to gender, especially in the retired persons and the rest of the inactive persons $(p<0.01)$.

The most predominant profile according to the professional stats in the job performed was one of a salaried employee or employee with an indefinite contract (49.6\%), obtaining a significant difference 
$(p<0.01)$, according to gender, in the profile of Employer, professional or self-employed person who employs others.

The type of household available to our sample was preferably the household in which couples with children cohabitation at home (41.2\%), followed by couples without children who cohabitated in the same household $(26.3 \%)$. Significant differences $(p<0.01)$ were obtained depending on the gender for the "single father or mother cohabitation with some children". We must also highlight that, although there is not much difference between those participants who have a secondary housing availability and those who do not. Furthermore, neither significant differences were obtained by gender.

The type of accommodation chosen by our sample on their trips is predominantly the family, friend, or company housing $(34.5 \%)$, followed by homeownership and hotels or apartment hotels $(12.2 \%)$. Significant differences were found according to gender $(p<0.01)$, since a very different value seems to be observed in "shared use housing", since no man made use of this type of accommodation. This variable is of special interest to the hotel sector since the proposed offer may not be of interest to this tourist profile, so a review of the tour packages possibly demanded by trekking tourists is suggested. A sustainable tourist package that includes accommodation, healthy food, guidance, a network of geolocated routes, sustainable travel to destinations, and the sale and rental of material for trekkers such as walking sticks, boots, GPS, and maps may be attractive to this tourist profile.

Finally, one of the most interesting variables when it comes to studying more sustainable measures aimed at this type of tourist is the most widely used means of transport. As can be expected, car or other private owned or leased cars, was the most popular option $(84.9 \%)$, and perhaps the least sustainable of all, followed by air transport (7.1\%). We have to take into account what this means because as indicated by the World Health Organization (WHO), the air we breathe is contaminated by emissions from motor vehicles so that exposure to these particles is a decrease in quality of life [25]. In this variable, significant differences were also obtained according to gender $(p<0.01)$, since cruises are more chosen by men and buses by women.

Once we know the profile and travel habits of our tourists, we consider it vital to reduce the use of private transport as the main means. Therefore, we propose a service offering that allows tourists to travel from the nearest urban centers to the trekking destinations in a collective way using sustainable means of transport managed by private companies. This will allow the creation of jobs in order not to massify the natural spaces with cars since this implies a significant visual impact and also a high level of pollution. This would help to preserve the quality of the air, allowing certain species that are bio-indicators of environmental quality to continue living in these destinations that combine environmental richness with the constant presence of human beings. An example of this is the "Garganta de los Infiernos Nature Reserve" in Jerte (Cáceres, Spain), a well-known trekking destination that is very crowded in summer periods. The measure adopted has been limiting the access to the reservation exclusively to authorized cars, specifically for tourism, and access to the reservation is only permitted in cars of AT companies, which have also been limited in the number of trips permitted per day. These cars should be replaced by more sustainable ones since those which are mainly used are quite old and highly polluting four-wheel drive cars. This measure contributes particularly to the development of sustainable development goals 3 (Promoting healthy lifestyles in all ages) and 8 (Creating an economic action plan based on sustainable tourism) [16]. It is known that through this type of tourism, resources, and mechanisms of environmental protection can be obtained, in order to extend the natural conservation of a particular area. However, it is always important to carry out an optimal implementation, otherwise, there is a risk of devastation to the environment [26]. In the same way, it should be remembered that both the global positive impacts perceived by the tourist, and the satisfaction experienced with the consumption of this tourism type, positively influence the attitude towards sustainable tourism development [27].

It should be noted that this study has certain limitations that we should consider. Firstly, we cannot take the size of the sample as a representative, since we have a small number of participants compared to the actual number of tourists who travel within our country each year and who go trekking. 
For example, it is estimated that every year several thousand people walk through "El Camino de Santiago". Therefore, the data presented should be treated with caution. Secondly, another limitation of the study is the impossibility of knowing the real destination of the practice of trekking, so we cannot know which are the favorite or most practiced paths by our tourists. However, if we knew this information, it would make it much easier to design more sustainable practices focused on this type of tourism.

As future lines of research, we propose to the scientific community the possibility of extending the object of study by taking foreign tourists as a sample, to be able to identify more accurately the profile and interests of those people who demand or practice trekking during their trips. By this way, more appropriate measures could be designed or established to reduce the impact on the environment and to be able to control the residual impact once the appropriate measures have been established to make this type of tourism a sustainable option. We also consider that it would be interesting to know the type of most demanded trails in terms of difficulty, environment, and proximity to urban centers, to enable the design of more sustainable routes in terms of signposting, waste management, and land erosion.

\section{Conclusions}

Once the variables included in this study have been analyzed, using the results obtained in the National Tourism Survey of Residents in 2019, and to identify the profile of tourists who go trekking on their trips to design measures to reduce the environmental impact, we conclude that the majority profile corresponds to married men, who live with their partner and who have a high level of academic education. In terms of professional profiles, they are employed by others and employees with a permanent contract. Likewise, they mostly use their car as the main means of transport on their trips and choose the family, friend, or company housing as their favorite accommodation. It should be noted that significant differences were obtained in practically all the variables studied according to gender, there were even more women than men when the study finished. The most notable differences were in foreign nationality, widowhood, the level of Post- Secondary Education, the number of retired people, the professional status in the job performed, the single father or mother cohabitation with some children, shared use housing, and the means of transport used.

This information is relevant for the design of sustainable tourism products, to achieve sustainable development goals and to achieve a positive attitude towards sustainable tourism development for several reasons. By understanding the priorities of this tourist profile, more sustainable sporting activities in nature can be developed, better development and protection of the environment, in general, can be achieved, and tourists will be more satisfied with being able to go trekking or to do other sports activities in amazing and well-preserved places.

Author Contributions: Conceptualization, J.R.-R., R.M.-C., C.G.-A., F.M.-R. and J.C.A.; Formal analysis, J.R.-R., M.A.G.-G. and J.C.A.; Funding acquisition, M.A.G.-G.; Methodology, J.R.-R., R.M.-C., C.G.-A., F.M.-R., M.A.G.-G. and J.C.A; Software, J.R.-R., R.M.-C., C.G.-A., F.M.-R. and J.C.A; Writing-original draft, J.R.-R., R.M.-C., C.G.-A., F.M.-R., M.A.G.-G. and J.C.A; Writing-review \& editing, J.R.-R., R.M.-C., C.G.-A., F.M.-R. and J.C.A. All authors have read and agreed to the published version of the manuscript.

Funding: This research received no external funding.

Conflicts of Interest: The authors declare no conflict of interest.

\section{References}

1. Bento, P.; Murta, L.; Sáez-Padilla, J. La calidad de los servicios de las empresas de turismo activo en Portugal. Cuad. Tur. 2019, 44, 27-41. [CrossRef]

2. Olivera, A.; Olivera, J. Las actividades físicas de aventura en la naturaleza. Estudio de la oferta y la demanda en el sector empresarial. [Physical and adventure activities in the nature. A Study of supply and demand in the business sector]. Apunt. Educ. Física Deportes 1999, 57, 86-94. 
3. Molina Navarro, F.; Rivera Mateos, M.; Millán Vázquez de la Torre, G. El estudio de la oferta empresarial de destinos de turismo activo en España: Análisis crítico y propuestas de investigación. Int. J. Sci. Manag. Tour. 2017, 3-4, 555-589.

4. Andalucía Exclusiva. Qué es el Turismo Activo. 2016. Available online: https://www.andaluciaexclusiva. com/experiencias/turismo-activo/ (accessed on 30 October 2020).

5. Ayora, A. Gestión del Riesgo en Montaña y en Actividades al Aire Libre; Desnivel: Madrid, Spain, 2011.

6. Cánovas, E.R.; Castiñeira, C.B. El patrimonio cultural en los procesos de renovación de áreas turísticas litorales. Una aproximación al destino turístico de la Costa Blanca (Alicante, España). Cuad. Geográficos 2016, 55, 299-319.

7. Mediavilla Saldaña, L. Parámetros para la valoración de la calidad en las empresas de turismo activo, a través del diseño de un instrumento multidimensional. Ágora Educ. Física Deporte 2008, 7, 63-98.

8. Cerrillo Vidal, J.A. Medición de la conciencia ambiental: Una revisión crítica de la obra de Riley E. Dunlap. Athenea Digit. Rev. Pensam. Investig. Soc. 2010, 17, 33-52.

9. De Oliveira-Matos, C.; Chim-Miki, A.F.; Mediana-Brito, P.; Batista-Canino, R.M. Senderismo como Modalidad Turística: Una Oportunidad Competitiva para Brasil. PODIUM Sport Leis. Tour. Rev. 2017, 6, 427-449. [CrossRef]

10. Weber, K. Outdoor adventure tourism: A review of research approaches. Ann. Tour. Res. 2001, 28, 360-377. [CrossRef]

11. Różycki, P.; Dryglas, D. Trekking as a phenomenon of tourism in the modern world. Acta Geoturistica 2014, 5, 24-40.

12. Rodríguez Rodríguez, M.; Rodríguez Campo, L. El senderismo dentro del contexto experiencial del turismo actual: ¿ocio o negocio? Decisión 2010, 21-42.

13. Luque-Gil, A.M. Las actividades recreativo-deportivas y el uso turístico del medio rural. Univ. Málaga 2003.

14. Tojo, J.F.; García, E.H. Turismo y uso sostenible del territorio. El senderismo como posibilidad para los pequeños municipios. Cuad. Investig. Urbanística 1999, 1-69.

15. Organization, W.T. Tourism Highlights: 2005 Edition; WTO Madrid: Madrid, Spain, 2005.

16. Sostenible, D. Objetivos de Desarrollo Sostenible. FAO 1986.

17. Brockelman, W.Y.; Dearden, P. The role of nature trekking in conservation: A case-study in Thailand. Environ. Conserv. 1990, 17, 141-148. [CrossRef]

18. Nyaupane, G.P.; Lew, A.A.; Tatsugawa, K. Perceptions of trekking tourism and social and environmental change in Nepal's Himalayas. Tour. Geogr. 2014, 16, 415-437. [CrossRef]

19. Crosby, A. Elementos Básicos Para un Turismo Sostenible en las Áreas Naturales; Forum Natura: Madrid, Spain, 1996.

20. Inskeep, E. Guía para Administraciones Locales: Desarrollo Turístico Sostenible; Organización Mundial del Turismo: Madrid, Spain, 1999.

21. Beedie, P.; Hudson, S. Emergence of mountain-based adventure tourism. Ann. Tour. Res. 2003, 30, 625-643. [CrossRef]

22. Sotomayor Mosquera, P.R.; Sosa Bolaños, D.I.; Parra Cárdenas, H.A. Diagnóstico del nivel de actividad física y el senderismo en sangolquí: Estudio por rango etario. Rev. Cuba. Investig. Biomédicas 2017, 36, 1-22.

23. Balderas Elorza, C.R. Características de la demanda de turismo de naturaleza y de aventura en Playa del Carmen. Teoría Prax. 2014, 9, 9-48. [CrossRef]

24. Mill, R.C. Tourism: The International Business; Prentice-Hall: Englewood Cliffs, NJ, USA, 1990.

25. WHO. WHO Global Urban Ambient Air Pollution Database (Update 2016); WHO: Geneva, Switzerland, 2016; pp. 1-121.

26. Fariña, J.; Higueras, E. Turismo y uso sostenible del territorio. Cuad. Investig. Urbanística 1999, $28,1-70$.

27. Santos-Roldán, L.; Castillo Canalejo, A.M.; Berbel-Pineda, J.M.; Palacios-Florencio, B. Sustainable Tourism as a Source of Healthy Tourism. Int. J. Environ. Res. Public Health 2020, 17, 5353. [CrossRef] [PubMed]

Publisher's Note: MDPI stays neutral with regard to jurisdictional claims in published maps and institutional affiliations. 